\title{
Relationship of Destination Image, Sports Involvement, Event Quality, and Travel Motives as an Antecedent Factors on Revisit Intention in Recurring Running Sports-Event
}

\author{
Tara Setyaningtyas $^{1}$; Annesa Nariswari Kirana ${ }^{2 *}$; Muhammad Angga Wicaksono ${ }^{3}$ \\ ${ }^{1,2,3}$ Creative Marketing Department, Management Department, \\ BINUS Business School Master Program, Bina Nusantara University \\ Jl. Hang Lekir I No. 6, RT. 1/RW. 6, Senayan, Jakarta Pusat 10271, Indonesia \\ 1'tarasetyaningtyas@gmail.com; ${ }^{2}$ annesa.kirana@gmail.com; ${ }^{3}$ anggawicaksono91@gmail.com
}

Received: $15^{\text {th }}$ June 2021/ Revised: $28^{\text {th }}$ July 2021/ Accepted: $19^{\text {th }}$ August 2021

\begin{abstract}
How to Cite: Setyaningtyas, T., Kirana, A. N., \& Wicaksono, M. A. (2021). Relationship of destination image, sports involvement, event quality, and travel motives as an antecedent factors on revisit intention in recurring running sports-event. The Winners, 22(2), 137-146. https://doi.org/10.21512/tw.v22i2.7434
\end{abstract}

\begin{abstract}
The research aimed to examine the relationship between destination image, sports involvement, quality of sport events, and travel motives as antecedent factors to predict repeat visit intentions of marathon events. Data were collected using a quantitative, non-probability, purposive sampling methods. The research instrument was an online questionnaire which was distributed to tourists and athletes who took part in running sportevents. Data analysis method used Structural Equation Modelling with Smart PLS 3.0. The test results show that not all research hypotheses are accepted. Sportevent quality (SQ) has a positive relationship but has no significant effect on revisit intention (RI) from repeated sporting events. The positive effect of travel motive (TM) on the intention to revisit a repetitive sporting event (RI) is proven. Travel motive (TM) also has a positive and significant effect on destination image (DI). Sports involvement (SI) has a positive and significant effect on revisit intention (RI). The same positive and significant effect is also shown in the relationship between sports event quality (SQ) and destination image (DI) variables. Revisit intention (RI) of repeated sporting events was found to be positively influenced by destination image (DI). There is a significant indirect effect of sport-event quality on intention to revisit repeated sporting events (RI), mediated by destination image.
\end{abstract}

Keywords: destination image, sport involvement, sport-event quality, travel motives, revisit intention

\section{INTRODUCTION}

Sport has evolved from being a means of gaining physical fitness into a large-scale and profitable industrial event. Realizing this, many countries are willing to invest heavily to be selected and maximize the opportunity to host a respected sport event. As a result, the management of sporting events has grown exponentially in recent years (Priporas et al., 2018).

From a tourism perspective, organizing sport events, especially in the form of recurring ones, is an effective means of promotion, and the success of its implementation will shape the nation's competitive position (Fairley, Kellett, \& Green, 2007) thus giving birth to the term sport-tourism. The success of organizing sport events on a recurring basis will be able to become an economic stimulus (Schneider, 2009) since it brings economic benefits (and foreign exchange) for the host country or region (Perić, Vitezić, \& Badurina, 2019).

There is an increase in the number of tourists and the formation of positive perceptions and images as a brand destination that is worthy of consideration for the location and host country (Kaplanidou \& Gibson, 2010). This phenomenon is in line with the characteristics of the modern economy which has shifted from product-service-based to experiencebased from all events held (including atmosphere, additional events) (Coetzee et al., 2019), even the experience of obtaining and buying publications, souvenirs, and gifts as well as the impression of local culture (Dirsehan, 2012). Consumer involvement and the ability to feel the uniqueness of certain tourist destinations are also related to the presence of clear 
and visual information on related tourist destinations (Priporas et al., 2018).

Destination image is measured based on the natural environment, atmosphere, and entertainment (Chen et al., 2021). In general, the construction of extraordinary experience gain (for sport events) is outlined by Coetzee et al. (2019) in the form of a holistic prima model that includes elements of design and programming, physical organization, social interaction, personal gain, symbolic meaning, and communication. Moreover no less important is eventservice quality as an overall judgment of and attitude toward the value of experience of an event attribute (Chen et al., 2021).

The strength of the destination brand will result in revisit intention, namely the tendency and intention of tourists (and athletes as participants in the sports being competed) to revisit locations and countries that have successfully organized sport events. Revisit intention can be analogized as repurchase intention which reflects success, especially since the brand requires the loyalty of its buyers for the survival (Jeong, Yu, \& Kim, 2020).

The embodiment of the revisit intention can be in the form of interest, motivation, or intention to visit is accompanied by the hope to get higher level of satisfaction on the next visit (Yang, 2011). The revisit intention is closely related to the satisfaction of tourists (athletes) from previous visits as the emotional response to and positive emotional association with the outcome of an experience. The judgment itself reaches after an evaluation and helps distinguish between expectation and authentic experience (Chen et al., 2021).

The benefits of revisit intention include: 1) an opportunity to break away from daily routines; 2) relaxation; 3) means of social interaction; 4) the realization of a certain prestige; 5) the embodiment of prestige; 6) cultural and learning experiences; 7) knowledge exploration. Meanwhile, the dominant motive for female tourists is as an opportunity to socialize, relax, and gain experience and opportunity to explore culture and knowledge (Funk et al., 2007).

Revisit intention is influenced by various essential antecedent factors in the form of images and impressions obtained (Kaplanidou et al., 2012), strong intentions and behavioural problems (Alegre \& Cladera, 2006; Kaplanidou \& Gibson, 2010; Kaplanidou et al., 2012), brand goals formed (Parent et al., 2012), and consumption behavior (Woo-Sik et al., 2016). Inconsistent results have been shown in several recent years research and development of theories on intention to revisit sporting events.

Sport-event quality is closely related to positive responses and behaviors in the form of increasing the frequency and intensity of participation, satisfaction, engagement, commitment, and visitor loyalty including tourists' and athletes' (Brady et al., 2006; Chalip, Green, \& Hill, 2003; Yoshida \& James, 2011). Sport event quality is the audience's perception of the quality of the core product (sports) and secondary product of the main product (Foroughi et al., 2014 and Jin et al., 2015). These two types of perceptions will shape the perception of consumer value, which will have a significant impact on consumer intentions and behavior to revisit the location and country of the sport event organizer (Jin et al., 2015). Hence, the hypothesis will be:

Hypothesis $1\left(H_{p}\right)$ : Sport-event quality has a positive and significant effect on revisit intention.

Travel motives are an individual's inner state, both in the form of beliefs, thoughts, and feelings, as well as the needs and desires of tourists and athletes, so they are considered as one of the most influential factors (Li \& Cai, 2012). These travel motives are generated from attraction, the desire to revitalize oneself, personal connections, site attributes, and travel features (Van Der Merwe et al., 2011). Furthermore, there are factors that motivate visitors, which include: 1) the opportunity to adapt to the culture, values, attitudes, and behavior that are typical of the destination tourist destination; 2) a self-reflection; and 3 ) representation of tourists and athletes (Priporas et al., 2018).

Several models that are often used as a guide in empirical studies of travel motives include: 1) pushpull (Dann, 1977); 2) psychocentric allocation (Plog, 1974); 3) the search for escape (Ross \& Iso-Ahola, 1991); and 4) the career ladder model (Pearce \& Lee, 2005).

Push and pull as the most used model consists of: 1) internal factors as driving factors for tourists and athletes to travel; and 2) pull factors in the form of external incentives to direct tourists to certain tourist destinations based on their features or attributes (Hashemi et al., 2007). The hypothesis will be:

\section{Hypothesis $2\left(H_{2}\right)$ : Travel motives have a positive a significant effect on revisit intention.}

Sport involvement can be described as a multifaceted construction which is the main component in determining the certainty of participation in sporting events, with hedonic and symbolic value content in it (Beaton et al., 2011) and is assessed as part of sports motivation in the Psychological Continuum Model (Funk et al., 2017) which uses a psychological scale as the basis for measurement. Participants (athletes) with a stronger level of psychological relationship with sport events will have a higher level of sport involvement (Filo et al., 2013; Priporas et al., 2018). Hence the hypothesis will be:

\section{Hypothesis $3\left(H_{3}\right)$ : Sport involvement has a positive and significant effect on revisit intention.}

Factors that determine the quality of sporting events are: 1) the quality of access, accommodation, venues and matches (Shonk \& Chelladurai, 2009); 2) the quality of the physical environment, interactions, 
and outcomes (Theodorakis, Kaplanidou, \& Karabaxoglou, 2015), and 3) the activities, attractions, facilities, and additional services provided (especially for athletes). The details of these factors are in line with the assertion of Foroughi et al. (2014) that the quality of sport events is largely determined by the sub-dimensions of the core product (performance and operating time) and secondary products (entertainment areas and daily necessities services) (Foroughi et al., 2014). In general, it is believed that there will be a positive and significant relationship between service quality during sport events and destination image (Moon et al., 2011), even service quality is the main determining factor for sports event visitor satisfaction (Lee et al., 2018). Thus the hypothesis will be:

\section{Hypothesis $4\left(H_{4}\right)$ : Sport-event quality has a positive} and significant effect on destination image.

From results of research on the influence of travel motives and impressive tourism on destination image, it is evident that these two variables influence destination image (Dagustani et al., 2018). Other research also proves that travel motives have positive relationship with tourists' perceptions and attitudes towards certain tourist destinations (Pereira, Gupta, \& Hussain, 2019). Thus, the hypothesis will be:

Hypothesis $5\left(H_{5}\right)$ : Travel motives have a positive a significant effect on destination image.

Destination image is a direct antecedent of perceived quality, satisfaction, and intention to repurchase the quality and satisfaction obtained (Bigné et al., 2001). Chen and Tsai (2007) and Pratmaningsih et al. (2014) state that destination image have direct and indirect impacts on revisit intention. Therefore, the image of the destination serves as a component in the psychological continuum model, It will have an impact on the beliefs and tastes of tourists, which provides benefit to the host of the sport event organizer. The psychological continuum model is able to explain the image associated with the host's destination, and sporting events are positively related to the attachment and loyalty of tourists and athletes (Zhang et al., 2019), so that the perception of tourists will increase if the frequency of their visits increases (Pratminingsih, 2014).

The destination image scale consists of cognitive and affective aspects, and consists of 15 measurement items including the quality of sporting events, shopping facilities, accommodation quality, and related location safety (Jeong \& Kim, 2020) as well as reflections of expectations for tourist destinations (Crompton, 1979; Chen \& Funk, 2010)

Factors that influence the image of a destination are (1) financial factors such as low entry fees, the amount of prize money, and low overall costs; (2) personal factors such as friends who are leaving or a partner-family wanting to visit the site; and (3) management factors including whether the event is well organized, has exclusive features (difficult to qualify), provide special travel and accommodation packages, or receives a lot of media coverage (Priporas et al., 2018).

Revisit intention is the intention and desire to repeat a visit to a certain destination, within a certain period of time, which is closely related to the destination image, perceived quality, perceived value, and satisfaction from previous visits (Stylos et al., 2016). In addition to these intentions and desires, the reflection of revisit intention is in the form of a willingness to recommend related destinations to other parties (Allameh et al., 2015) and such wordof-mouth marketing enables potential tourists to accumulate knowledge about a destination (Jeong et al., 2020).

Better destination image, which is also the accumulation of beliefs, ideas, and impressions, leads to higher revisit intention (Kotler et al. in Lopes, 2011). Therefore, the hypothesis is formulated:

\section{Hypothesis $6\left(\mathrm{H}_{0}\right)$ : Destination image has a positive and significant effect on revisit intention.}

Destination image is a form of individual mental representation in the form of knowledge (beliefs), feelings, and overall perceptions about a particular tourist destination (Crompton, 1979; Fakeye \& Crompton, 1991). Destination image, which is reinforced by the motivation to vacation, is rated as one of the main factors influencing motivation and behavioral intention (Getz \& Andersson, 2010; Filo et al., 2013; Lee et al., 2005).

Since sport-event quality is also determined by the quality of matters not directly related to competitive activities, it is necessary to pay attention to non-sports matters such as accommodation facilities, attractiveness of cultural attractions or historical heritage, and available sports facilities combined with profile descriptions of related tourist destinations (Kaplanidou \& Gibson, 2010).

A well-maintained destination image plays an important role in mediating sport-event quality, travel motives and revisit intentions, which implies a promise of safety, comfort, and convenience. Destination image is also much determined by the quality of service during sport events (Moon et al., 2013). In general, the destination image, which consists of affective, mental, and unique images, has a positive and significant effect on revisit intention (Bhat \& Darzi, 2018) and tourist satisfaction (Huang et al., 2015). Hence, the hypothesis is formulated:

Hypothesis $7\left(H_{-}\right)$: Sport-event quality and travel motives together through destination image as mediating variable have a positive and significant effect on revisit intention.

Based on the various descriptions and research results, the research model is described in Figure 1. 


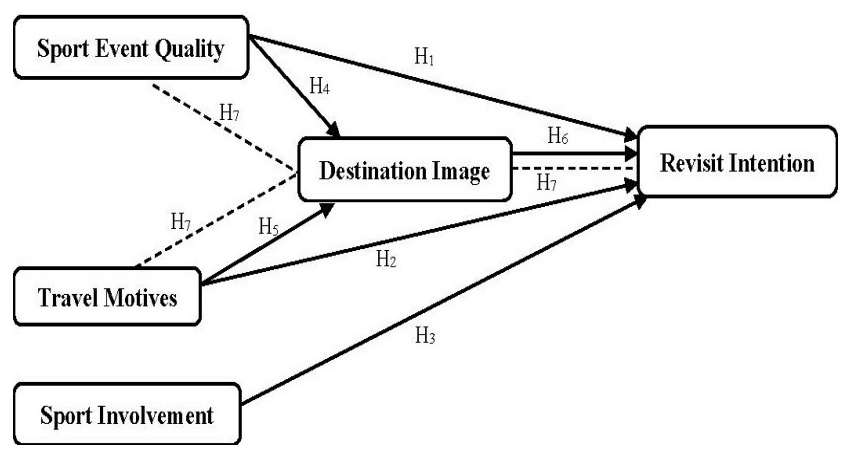

Figure 1 Hypothesized Model: Sport Event Quality, Travel Motives, Sport Involvement, Destination Image, and Revisit Intention

(Source: Author, 2021)

\section{METHODS}

The research intends to prove the link between several factors to influence the formation of revisit intention, i.e., sport event quality, destination image, travel motives, and sport involvement. This is a survey research since data collection procedure is conducted by distributing questions or statements to respondents in written form. A questionnaire is developed to collect data from participants who join various recurring marathon events located in Indonesia, so the research includes non-probability sampling and purpose sampling since specific criteria of respondents has been set.

The questionnaire is administered through online survey to assess participants. Survey research was conducted in June 2020 before the COVID-19 pandemic entered Indonesia, by collecting data through giving questions or statements to respondents in online survey form distributed through Jakpat online survey platform. The questionnaire was developed to collect data from Jabodetabek (Jakarta, Bogor, Tangerang, Depok, and Bekasi) random runner community such as Indo Runners and running participant who joined various recurring marathon event held in 2013-2019. The requirement for respondents of the research are that they have participated in a marathon recurring sport event. Furthermore, 500 questionnaires are distributed with response rate of $63,2 \%$ with 316 responses returned.

To measure the variables, five-point scale questions are developed ( $1=$ strongly disagree; $2=$ disagree; $3=$ neutral; $4=$ agree; $5=$ strongly agree). Sport event quality is measured by three primary dimensions, which are physical environment quality, interaction quality, and outcome quality (Alexandris et al., 2004; Nicholas et al., 2015). Travel motives is measured by seven dimensions which include socialization, escape, prestige, relaxation, cultural experience, knowledge exploration, and cultural learning (Funk et al., 2007). Destination image is developed based on the estimation or understanding of region characteristics and is measured by 18 items including socioeconomic environment, atmosphere, natural environment, affective image, and cultural environment (Chen \& Tsai, 2007; Jeong \& Kim, 2019). Sport involvement is measured by five dimensions, namely mundane-fascinating, valuable-worthless, not needed-needed, involving-not involving, and important-not important (Funk et al., 2007). Revisit intention is measured by respondent decision about the likeness to revisit the same destination (Funk, 2010) or the willingness to recommend others about the destination (Chen \& Tsai, 2007; Sato et al., 2018)

In conducting data analysis, the research uses the Structural Equation Modeling (SEM) equation model using SmartPLS version 3.0 software. This approach is an alternative to the SEM approach with the covariance base being the variance basis. Through this approach, the prediction of the relationship between constructs is carried out through three stages: 1) the outer model, 2) the inner model, and 3) hypothesis testing.

\section{RESULTS AND DISCUSSIONS}

In Table 1, profile of 316 respondents show that $62,03 \%$ of our respondents is male. As the object of research, the respondents come from millennial age group (26-35 years), who are also the main enthusiast of the sport-event marathon. The respondents are dominantly employees.

Table 1 Profile of Respondents

\begin{tabular}{ccc}
\hline Category & Frequency & Percentage (\%) \\
\hline Gender & & \\
Male & 196 & 62,03 \\
Female & 120 & 37,97 \\
Age & & \\
$15-25$ & 109 & 34,50 \\
$26-35$ & 144 & 45,57 \\
$36-45$ & 50 & 15,82 \\
$\geq 46$ & 13 & 4,11 \\
Profession & & \\
Student & 39 & 12,34 \\
Employee & 189 & 59,81 \\
Own Business & 36 & 11,40 \\
Other & 52 & 16,45 \\
\hline
\end{tabular}

Sources: Researcher (2021)

In carrying out the analysis with SEM approach, the outer model is first analyzed to ensure the validity and reliability of the instruments in the measurements made. This is done by looking at the results of the convergent validity and discriminant validity values. The convergent validity value shows the results of the loading factor on the latent variable with the indicators in the research with the expected value $>$ 
0,7. In addition, discriminant validity which is the value of the factor, is also considered by comparing the Average Variance Extracted (AVE) value of each variable construct with the correlation between other variable constructs in the model. The discriminant validity is declared good if the AVE of each construct gets a value higher than 0,5 . As provided in Table 2, all variables of discriminant validity are valid with AVE value of each construct higher than 0,5 . Table 2 shows that all values for the outer loading factor are above 0,7 which indicates that all research data are reliable.

Table 3 and Table 4 show the discriminant validity of the data, as seen from the cross-loading value of each measuring instrument which is greater than the cross-loading for other latent variables. The results of Forner Larcker's criteria analysis (Table 5) also show that all construct values are greater than the correlation value between latent variables. The measurement of internal consistency uses the results of the composite reliability and AVE analysis previously presented in Table 2, where for all variables, the composite variable value is more than 0,7 and the AVE value is more than 0,5 . In general, the results of the analysis presented in Table 2 to Table 5 indicate that the outer model is valid. In processing the data, some indicator variables are omitted, in accordance with the designation of the PLS SEM method to test exploratory and predictive theories.

Table 2 Reliability and Convergent Validity of Different Constructs

\begin{tabular}{lcccc}
\hline \multicolumn{1}{c}{ Variable } & $\begin{array}{c}\text { Cronbach's } \\
\text { Alpha }\end{array}$ & rho_A & Composite Reliability & $\begin{array}{c}\text { Average Variance } \\
\text { Extracted (AVE) }\end{array}$ \\
\hline Destination Image (DI) & 0,960 & 0,961 & 0,964 & 0,675 \\
Revisit Intention (RI) & 0,901 & 0,903 & 0,931 & 0,772 \\
Sport Involvement (SI) & 0,937 & 0,938 & 0,947 & 0,665 \\
Sport Event Quality (SQ) & 0,948 & 0,948 & 0,955 & 0,657 \\
Travel Motives (TM) & 0,914 & 0,915 & 0,930 & 0,624 \\
\hline
\end{tabular}

Sources: Researcher (2021)

Table 3 Outer Loadings

\begin{tabular}{|c|c|c|c|c|c|}
\hline Variable & DI & RI & SI & SQ & TM \\
\hline DI_10 & 0,828 & & & & \\
\hline DI_12 & 0,891 & & & & \\
\hline DI_13 & 0,876 & & & & \\
\hline DI_14 & 0,827 & & & & \\
\hline DI_15 & 0,789 & & & & \\
\hline DI_16 & 0,804 & & & & \\
\hline DI_17 & 0,781 & & & & \\
\hline DI_18 & 0,773 & & & & \\
\hline DI_2 & 0,816 & & & & \\
\hline DI_3 & 0,792 & & & & \\
\hline DI_5 & 0,834 & & & & \\
\hline DI_6 & 0,843 & & & & \\
\hline DI_7 & 0,818 & & & & \\
\hline RI_1 & & 0,905 & & & \\
\hline RI 2 & & 0,864 & & & \\
\hline RI_3 & & 0,897 & & & \\
\hline RI_4 & & 0,846 & & & \\
\hline SI_1 & & & 0,729 & & \\
\hline SI_2 & & & 0,825 & & \\
\hline SI_3 & & & 0,833 & & \\
\hline SI_4 & & & 0,841 & & \\
\hline SI_5 & & & 0,854 & & \\
\hline SI_6 & & & 0,822 & & \\
\hline
\end{tabular}

Table 3 Outer Loadings (Continued)

\begin{tabular}{|c|c|c|c|c|c|}
\hline Variable & DI & RI & SI & SQ & TM \\
\hline SI_7 & & & 0,810 & & \\
\hline SI_8 & & & 0,834 & & \\
\hline SI_9 & & & 0,784 & & \\
\hline SQ_10 & & & & 0,755 & \\
\hline SQ 11 & & & & 0,777 & \\
\hline SQ_2 & & & & 0,791 & \\
\hline SQ_3 & & & & 0,811 & \\
\hline SQ_4 & & & & 0,819 & \\
\hline SQ_5 & & & & 0,845 & \\
\hline SQ_6 & & & & 0,823 & \\
\hline SQ_7 & & & & 0,849 & \\
\hline SQ_8 & & & & 0,825 & \\
\hline SQ_9 & & & & 0,801 & \\
\hline SQ_1 & & & & 0,815 & \\
\hline TM_12 & & & & & 0,801 \\
\hline TM_13 & & & & & 0,822 \\
\hline TM_14 & & & & & 0,775 \\
\hline TM_15 & & & & & 0,774 \\
\hline TM_16 & & & & & 0,776 \\
\hline TM_17 & & & & & 0,792 \\
\hline TM_18 & & & & & 0,793 \\
\hline TM_19 & & & & & 0,786 \\
\hline
\end{tabular}

Sources: Researcher (2021) 
Table 4 Discriminant Validity for Different Items-Cross Loading Results

\begin{tabular}{lccccc}
\hline Variable & DI & RI & SI & SQ & TM \\
\hline DI_10 & 0,828 & 0,631 & 0,571 & 0,582 & 0,605 \\
DI_12 & 0,891 & 0,726 & 0,637 & 0,657 & 0,682 \\
DI_13 & 0,876 & 0,712 & 0,611 & 0,637 & 0,653 \\
DI_14 & 0,827 & 0,650 & 0,542 & 0,598 & 0,599 \\
DI_15 & 0,789 & 0,649 & 0,609 & 0,601 & 0,681 \\
DI_16 & 0,804 & 0,593 & 0,525 & 0,566 & 0,588 \\
DI_17 & 0,781 & 0,599 & 0,528 & 0,559 & 0,583 \\
DI_18 & 0,773 & 0,613 & 0,595 & 0,522 & 0,641 \\
DI_2 & 0,816 & 0,686 & 0,588 & 0,622 & 0,660 \\
DI_3 & 0,792 & 0,618 & 0,664 & 0,601 & 0,696 \\
DI_5 & 0,834 & 0,690 & 0,610 & 0,597 & 0,651 \\
DI_6 & 0,843 & 0,699 & 0,597 & 0,612 & 0,647 \\
DI_7 & 0,818 & 0,615 & 0,593 & 0,594 & 0,658 \\
RI_1 & 0,723 & 0,905 & 0,661 & 0,672 & 0,656 \\
RI_2 & 0,741 & 0,864 & 0,602 & 0,610 & 0,643 \\
RI_3 & 0,679 & 0,897 & 0,632 & 0,613 & 0,608 \\
RI_4 & 0,649 & 0,846 & 0,650 & 0,544 & 0,548 \\
SI_1 & 0,571 & 0,642 & 0,729 & 0,602 & 0,507 \\
SI_2 & 0,605 & 0,573 & 0,825 & 0,531 & 0,598 \\
SI_3 & 0,570 & 0,619 & 0,833 & 0,569 & 0,555 \\
SI_4 & 0,568 & 0,610 & 0,841 & 0,562 & 0,551 \\
SI_5 & 0,577 & 0,607 & 0,854 & 0,560 & 0,584 \\
SI_6 & 0,560 & 0,608 & 0,822 & 0,506 & 0,620 \\
\hline & & & & &
\end{tabular}

Table 4 Discriminant Validity for Different Items-Cross Loading Results (Continued)

\begin{tabular}{lccccc}
\hline Variable & DI & RI & SI & SQ & TM \\
\hline SI_7 & 0,528 & 0,512 & 0,810 & 0,496 & 0,603 \\
SI_8 & 0,675 & 0,597 & 0,834 & 0,585 & 0,673 \\
SI_9 & 0,619 & 0,510 & 0,784 & 0,488 & 0,635 \\
SQ_10 & 0,641 & 0,567 & 0,630 & 0,755 & 0,628 \\
SQ_11 & 0,528 & 0,572 & 0,516 & 0,777 & 0,507 \\
SQ_2 & 0,521 & 0,563 & 0,519 & 0,791 & 0,502 \\
SQ_3 & 0,571 & 0,555 & 0,523 & 0,811 & 0,572 \\
SQ_4 & 0,579 & 0,553 & 0,513 & 0,819 & 0,529 \\
SQ_5 & 0,590 & 0,567 & 0,535 & 0,845 & 0,537 \\
SQ_6 & 0,588 & 0,518 & 0,506 & 0,823 & 0,525 \\
SQ_7 & 0,631 & 0,577 & 0,590 & 0,849 & 0,587 \\
SQ_8 & 0,604 & 0,515 & 0,570 & 0,825 & 0,574 \\
SQ_9 & 0,595 & 0,594 & 0,523 & 0,801 & 0,583 \\
SQ_1 & 0,616 & 0,612 & 0,544 & 0,815 & 0,565 \\
TM_12 & 0,596 & 0,530 & 0,562 & 0,541 & 0,801 \\
TM_13 & 0,639 & 0,535 & 0,567 & 0,539 & 0,822 \\
TM_14 & 0,677 & 0,638 & 0,579 & 0,593 & 0,775 \\
TM_15 & 0,596 & 0,647 & 0,585 & 0,561 & 0,774 \\
TM_16 & 0,661 & 0,582 & 0,601 & 0,568 & 0,776 \\
TM_17 & 0,605 & 0,530 & 0,536 & 0,520 & 0,792 \\
TM_18 & 0,572 & 0,436 & 0,562 & 0,494 & 0,793 \\
TM_19 & 0,574 & 0,485 & 0,574 & 0,503 & 0,786 \\
\hline & & & & &
\end{tabular}

Sources: Researcher (2021)

Table 5 Forner-Larcker Criterion for Different Construct in a Correlation Matrix

\begin{tabular}{lccccc}
\hline \multicolumn{1}{c}{ Variable } & DI & RI & SI & SQ & TM \\
\hline Destination Image (DI) & 0,822 & & & & \\
Revisit Intention (RI) & 0,796 & 0,878 & & & \\
Sport Involvement (SI) & 0,719 & 0,724 & 0,815 & & \\
Sport Event Quality (SQ) & 0,727 & 0,696 & 0,671 & 0,810 & \\
Travel Motives (TM) & 0,782 & 0,700 & 0,724 & 0,687 & 0,790 \\
\hline
\end{tabular}

Sources: Researcher (2021)

Table 6 Result for Different Path Coefficients of the Structured Model

\begin{tabular}{lccccc}
\hline \multicolumn{1}{c}{ Variable } & Original Sample & Sample Mean & Standard Deviation & T Statistics & P Values \\
\hline DI -> RI & 0,420 & 0,442 & 0,082 & 5,128 & 0,000 \\
SI -> RI & 0,257 & 0,244 & 0,070 & 3,654 & 0,000 \\
SQ -> DI & 0,363 & 0,372 & 0,060 & 6,035 & 0,000 \\
SQ -> RI & 0,120 & 0,122 & 0,066 & 1,809 & 0,071 \\
TM -> DI & 0,540 & 0,541 & 0,062 & 8,762 & 0,000 \\
TM -> RI & 0,139 & 0,136 & 0,059 & 2,348 & 0,019 \\
\hline
\end{tabular}

Sources: Researcher (2021) 
Table 6 provides the results of the analysis of the inner model or structural equation model to test the significance of the independent latent variables. The value of t-statistics is calculated through bootstrapping by re-sampling multiplication data from the existing sample to meet the statistical rules. Meanwhile, resampling for 1.000 iterations (Kamel \& Broc, 2018) is carried out based on the results tabulated in Table 5.

From the test results, not all research hypotheses are accepted, namely $\mathrm{H}_{1}$ which is not supported by this structured model. It is proven that sport-event quality (SQ) has a positive relationship but has no significant effect on revisit intention (RI) from repeated sporting events, which is reflected in the value of $=0,120$, $\mathrm{t}$-value $=1,809$, and $\mathrm{p}>0,001$. The research confirms a positive relationship between sport-event quality and revisit intention (Jin et al., 2015; Alsawafi, 2017) although sport-event quality does not always have a significant direct impact on the intention to participate in a repeated sporting event. The significance of the weak influence can be possible since the sport-event quality is perceived only as a part of consideration factor to return to the event, especially for millennials as the majority respondents of the research.

The positive effect of travel motives (TM) on the intention to revisit (RI) a repetitive sporting event is proven empirically based on the statistical significance of the path coefficient $(\beta=0,139, \mathrm{t}$ value $=2,348, p<0,001)$. Travel motives $(\mathrm{TM})$ also has a positive and significant effect on destination image (DI) $(\beta=0,540, \mathrm{t}$-value $=8,762, \mathrm{p}<0,001)$, thus $\mathrm{H}_{2}$ and $\mathrm{H}_{5}$ are supported. This shows that travel motives are one of the factors that encourage running enthusiasts to return and visit the recurring sporting events. Aspects of cultural experience, knowledge exploration, and cultural learning become motivations that encourage respondents to return to visit the event. This characteristic confirms that millennial sport tourists are driven by factors such as escaping from daily routine, exploring, sensationalizing, challenging, and stimulating adrenaline (IJspeert \& HernandezMaskivker, 2020) In addition, travel motives are also perceived to be the reinforcement of the destination image for the event he visited again (Dagustani et al., 2018). The positive relationship between travel motives and destination image also shows that aspects of travel motives form a cognitive image or an affective image which in turn will encourage revisit intention from respondents (Khan, Chelliah, \& Ahmed, 2017).

For the sports involvement variable, the results of the statistical model show that sports involvement (SI) has a positive and significant effect on revisit intention (RI) $(\beta=0,257, \mathrm{t}$ value $=3,654, \mathrm{p}<0,001)$, thus $\mathrm{H}_{3}$ is verified. Sport involvement as a psychological scale as the basis for measurement indicate that respondents who are running enthusiasts have higher sport involvement. It is seen as psychological value with hedonic and symbolic value content in it (Beaton et al., 2011; Filo et al., 2013; Priporas et al., 2018). The result also show the importance of understanding the psychological value of running enthusiasts to have revisit intention of recurring sport event (Mason et al., 2019).

Similar positive and significant effect is also shown in the relationship between sport event quality (SQ) and destination image (DI) variables $(\beta=0,363$, $\mathrm{t}$-value $=6,035, \mathrm{p}<0,001)$. These results support $\mathrm{H}_{4}$. Revisit intention (RI) of repeated sporting events is found to be positively influenced by destination image (DI) $(\beta=0,420, \mathrm{t}$-value $=5,128, \mathrm{p}<0,001)$, thus $\mathrm{H}_{6}$ is supported. The relationship between sportevent quality and destination image affirms previous research that indicate service quality during sport events as the main determining factor for visitors' satisfaction, which leads them to revisit behavioral intention (Kim et al., 2018). Furthermore, sport-event quality could contribute to co-create or create more value in the process of building destination image to attract visitors (Fam et al., 2020).

The mediation test is conducted to assess the indirect effect of travel motives (TM) on destination image (DI) and intention to return to a sport event (RI), as well as the indirect effect of sport-event quality (SQ) on destination image (DI) and intention to revisit sporting events (RI).

Table 7 shows the significant indirect effect of travel motives (TM) on intention to revisit a recurring sporting event (RI) under destination image as a mediating variable $(\beta=0,226, \mathrm{t}$ value $=4,573, \mathrm{p}<$ $0,001)$.

Table 7 shows that there is a significant indirect effect of sport-event quality on intention to revisit repeated sporting events $(\mathrm{RI})$, mediated by destination image $(\beta=0,152, \mathrm{t}$ value $=3,553, \mathrm{p}<0,001)$. The results prove that $\mathrm{H}_{7}$ is accepted. Therefore, the result affirms that a well-maintained destination image plays an important role in mediating sport-event quality, travel motives, and revisit intentions (Moon et al., 2013; Huang et al., 2015; Bhat \& Dharzi, 2018). Destination image as mediating variable also confirms that it can predict and influence future behavior (Kim, 2017).

Table 7 Indirect Effect of Destination Image as Mediating Variable on Revisit Intention

\begin{tabular}{cccccc}
\hline Variable & Original Sample & Sample Mean & Standard Deviation & T Statistics & P Values \\
\hline TM -> DI -> RI & 0,226 & 0,239 & 0,050 & 4,573 & 0,000 \\
SQ -> DI -> RI & 0,152 & 0,165 & 0,043 & 3,553 & 0,000 \\
\hline
\end{tabular}




\section{CONCLUSIONS}

The research aims to examine the relationship between sport-event quality, travel motives, sport involvement, and destination image (either directly or as a mediating variable between sport-event quality and travel motives) on revisit intention. The research is also to gain more comprehensive understanding on theory about how to create future behavioral intention from sport tourist on running sport event especially the recurring ones.

As theoretical contribution, the research proves that all those antecedents have a positive and significant influence, except for sport-event quality which has insignificant influence of future revisit intention. The result also contributes to prove that the mediating role of destination image can lead to future behavioral intention. In behavioral aspects, the results prove that the respondents, who are tourists and running enthusiasts, do not view the quality of sport as a top priority. They pay more attention to their participation in these sport events and their destination image in determining revisit intention. In other words, sport event participants are not dominated by actual athletes, but the public who treat sport-events as a part of tourism and are triggered by psychological motives.

As managerial contribution, the research provides managerial implication for sport event organizers, destination managers, and sport tourism marketers. First, sport event organizers should pay more attention to other factors besides sporting activities, which specially attract more visitors who come to sport events as psychological moments. In addition, event organizers are suggested to gain more understanding about visitors' motives such as escaping from daily routine, exploring, sensationalizing, challenging, and stimulating adrenaline for millennials sport tourist. Second, destination manager should pay more attention to build their environment so that sport tourists perceive the event as attractive destination. Third, marketer should consider millennials as important segment of sport tourists and grab their attention through attractive sport marketing communication which leads to psychological motives and values.

The research has its limitation since it is conducted online during pandemic COVID-19, so the respondents' perceived image and values may not be representative after the running event is done. The respondents are limited only to the runner participants of the recurring event, which do not include the spectator. For improvement, further research should consider expanding the research variables by adding the types of sports included as the main product of sport events, consider the spectator as research respondents especially during the COVID-19 pandemic, and incorporate elements of virtual tourism as a research basis. In addition, questionnaires can also be used and elaborated for further research development.

\section{REFERENCES}

Alegre, J. \& Cladera, M. (2006). Repeat visitation in mature sun and sand holiday destinations. Journal of Travel Research, 44(3), 288-297. https://doi. org/10.1177/0047287505279005.

Alexandris, K., Zahariadis, P., Tsorbatzoudis, C., \& Grouios, G. (2004). An empirical investigation of the relationships among service quality, customer satisfaction and psychological commitment in a health club context. European Sport Management Quarterly, 4(1), 36-52. https://doi. org/10.1080/16184740408737466.

Allameh, S. M., Pool, J. K., Jaberi, A., Salehzadeh, R., \& Asadi, H. (2015). Factors influencing sport tourists' revisit intentions: The role and effect of destination image, perceived quality, perceived value and satisfaction. Asia Pacific Journal of Marketing and Logistics, 27(2), 191-207. https://doi.org/10.1108/ APJML-12-2013-0159.

Alsawafi, A. M. (2017). Sport tourism: An exploration of the travel motivations and constraints of Omani tourists. Anatolia, 28(2), 239-249. https://doi.org/10 .1080/13032917.2017.1308388.

Beaton, A., Funk, D. C., Ridinger, L., \& Jordan, J. (2011). Sport involvement: An conceptual and empirical analysis. Sport Management Review, 14, 126-140. http://dx.doi.org/10.1016/j.smr.2010.07.002.

Bhat, S. A., \& Darzi, M. A. (2018). Antecedents of tourist loyalty to tourist destinations: a mediatedmoderation study. International Journal of Tourism Cities, 4(2), 261-278. https://doi.org/10.1108/IJTC12-2017-0079.

Brady, M. K., Voorhees, C. M., Cronin, J. J., Brian, J., Brady, M. K., Voorhees, C. M., ... \& Bourdeau, B. L. (2006). The good guys don't always win: The effect of valence on service perceptions and consequences. Journal of Services Marketing, 20(2), 83-91. https:// doi.org/10.1108/08876040610657011.

Chalip, L., Green, B. C., \& Hill, B. (2003). Effects of sport event media on destination image and intention to visit. Journal of Sport Management, 17(3), 214-234. https://doi.org/10.1123/jsm.17.3.214.

Chen, C-F. \& Tsai, D. (2007). How destination image and evaluative factors affect behavioral intentions? Tourism Management, 28(4), 1115-1122. https://doi. org/10.1016/j.tourman.2006.07.007.

Chen, N., \& Funk, D. C. (2010). Exploring destination image, experience and revisit intention: A comparison of sport and non-sport tourist perceptions. Journal of Sport \& Tourism, 15(3), 239-259. https://doi.org/10 $.1080 / 14775085.2010 .513148$.

Chen, X., Yim, B. H., Tuo, Z., Zhou, L., Liu, T., \& Zhang, J. J. (2021). "One event, one city": Promoting the loyalty of marathon runners to a host city by improving event service quality. Sustainability, 13(7), 1-13. https://doi.org/10.3390/su13073795.

Dagustani, D., Kartini, D., Oesman, Y. M., \& Kaltum, U. (2018). Destination image of tourist: Effect of travel motivation and memorable tourism experience. Etikonomi, 17(2), 307-318. https://doi.org/10.15408/ 
etk.v17i2.7211.

Dann, G. M. S. (1977). Anomie, ego-enhancement, and tourism. Annals of Tourism Research, 4, 184-194. http://dx.doi.org/10.1016/0160-7383(77)90037-8.

Dirsehan, T. (2012). Analyzing museum visitor experiences and post experience dimensions using SEM. Bogazici Journal, 26(1), 103-125. https://doi.org/10.21773/ boun.26.1.6.

Fairley, S., Kellett, P., \& Green, B. C. (2007). Volunteering abroad: Motives for travel to volunteer at the Athens Olympic Games. Journal of Sport Management, 21(1), 41-57. https://doi.org/10.1123/jsm.21.1.41.

Fam, K. S., Ting, H., Tan, K. L., Hussain, K., \& Cheah, J. H. (2020). Does it matter where to run? Intention to participate in destination marathon. Asia Pacific JournalofMarketingandLogistics, 32(7), 1475-1494. https://doi.org/10.1108/APJML-12-2019-0737.

Filo, K., Chen, N., King, C., \& Funk, D. C. (2013). Sport tourists' involvement with a destination: A stage-based examination. Journal of Hospitality \& Tourism Research, 37(1), 100-124. https://doi. org/10.1177\%2F1096348011425496.

Foroughi, B., Mohammad Shah, K. A., Nikbin, D., \& Hyun, S. S. (2014). The impact of event quality on fan satisfaction and game attendance in the context of professional soccer in Iran. International Journal of Sports Marketing and Sponsorship, 15(3), 40-56. https://doi.org/10.1108/IJSMS-15-03-2014-B005.

Funk, D. C., Toohey, K., \& Bruun, T. (2007). International sport event participation: Prior sport involvement; destination image; and travel motives. European Sport Management Quarterly, 7(3), 227-248. https:// doi.org/10.1080/16184740701511011.

Hashemi, S. M., Jusoh, J. Kiumarsi, S. \& Mohammadi, S. (2015). Influence factors of spa and wellness tourism on revisit intention: The mediating role of international tourist motivation and tourist satisfaction. International Journal of Research -GRANTHAALAYAH, 3(7), 1-11.

Huang, H., Lunhua Mao, L., Wang, J., \& Zhang, J. J. (2015). Assessing the relationships between image congruence, tourist satisfaction and intention to revisit in marathon tourism: The Shanghai International Marathon. International Journal of Sports Marketing and Sponsorship, 16(4), 46-66. https://doi.org/10.1108/IJSMS-16-04-2015-B005.

IJspeert, R. \& Hernandez-Maskivker, G. (2020). Active sport tourists: Millennials vs baby boomers. Journal of Tourism, Heritage \& Services Marketing, 6(2), 12-20. https://doi.org/10.5281/zenodo.3835813.

Jeong, Y. \& Kim, S. (2019). Exploring a suitable model of destination image: The case of a small-scale recurring sporting event. Asia Pacific Journal of Marketing and Logistics, 31(5), 1287-1307. https:// doi.org/10.1108/APJML-10-2018-0441.

Jeong, Y. \& Kim, S. (2020). A study of event quality, destination image, perceived value, tourist satisfaction, and destination loyalty among sport tourists. Asia Pacific Journal of Marketing and Logistics, 32(4), 940-960. https://doi.org/10.1108/ APJML-02-2019-0101.
Jeong, Y., Yu, A., \& Kim, S. K. (2020). The antecedents of tourists' behavioral intentions at sporting events: The case of South Korea. Sustainability, 12(1), 1-16. https://doi.org/10.3390/SU12010333.

Kamel, G. \& Broc, G. (2018). Structural Equation Modelling with Iavaan ( $1^{\text {st }}$ Ed.). Wiley.

Kaplanidou, K. \& Gibson, H. J. (2010). Predicting behavioral intentions of active event sport tourists: The case of a small-scale recurring sports event. Journal of Sport \& Tourism, 15(2), 163-179. https:// doi.org/10.1080/14775085.2010.498261.

Kaplanidou, K. K., Jordan, J. S., Funk, D., \& Rindinger, L. L. (2012). Recurring sport events and destination image perceptions: Impact on active sport tourist behavioral intentions and place attachment. Journal of Sport Management, 26(3), 237.248. https://doi. org/10.1123/jsm.26.3.237.

Khan, M. J., Chelliah, S., \& Ahmed, S. (2017). Factors influencing destination image and visit intention among young women travellers: Role of travel motivation, perceived risks, and travel constraints. Asia Pacific Journal of Tourism Research, 22(11), 1139-1155. https://doi.org/10.1080/10941665.2017. 1374985 .

Kim, J-H. (2017). The impact of memorable tourism experiences on loyalty behaviors: The mediating effects of destination image and satisfaction. Journal of Travel Research, 57(7), 856-870. https://doi.org/1 $0.1177 \% 2 \mathrm{~F} 0047287517721369$.

Kim, M. J., Lee, C. K., Petrick, J. F., \& Hahn, S. S. (2018). Factors affecting international event visitors' behavioral intentions: The moderating role of attachment avoidance. Journal of Travel and Tourism Marketing, 35(8), 1027-1042. https://doi.org/10.108 0/10548408.2018.1468855.

Li, M. \& Cai, L. A. (2012). The effects of personal values on travel motivation and behavioral intention. Journal of Travel Research, 51(4), 473-487. https://doi. org/10.1177/0047287511418366.

Mason, M. C., Moretti, A., Raggiotto, F., \& Paggiaro, A. (2019). Conceptualizing triathlon sport event travelers' behavior. Munich Personal RePEc Archive (pp. 1-12).

Moon, K-S., Ko, Y. J., Connaughton, D. P., \& Lee, J-H. (2013). A mediating role of destination image in the relationship between event quality, perceived value, and behavioral intention. Journal of Sport \& Tourism, 18(1), 49-66. https://doi.org/10.1080/1477 5085.2013.799960.

Pearce, P. L. \& Lee, U. (2005). Developing the travel career approach to tourist motivation. Journal of Travel Research, 43(3), 226-237. https://doi. org/10.1177/0047287504272020.

Pereira, V., Gupta, J. J., \& Hussain, S. (2019). Impact of travel motivation on tourist's attitude toward destination: Evidence of mediating effect of destination image. Journal of Hospitality and Tourism Research, (November). https://doi. org/10.1177/1096348019887528.

Perić, M., Vitezić, V., \& Badurina, J. Đ. (2019). Business models for active outdoor sport event tourism 
experiences. Tourism Management Perspectives, 32. https://doi.org/10.1016/j.tmp.2019.100561.

Plog, S. C. (1974). Why destinations areas rise and fall in popularity. Cornell Hospitality Quarterly, 14(4), 13-16. https://doi.org/10.1177\% 2F001088047401400409.

Pratminingsih, S. (2014). Roles of motivation and destination image in predicting tourist revisit intention: A case of Bandung - Indonesia. International Journal of Innovation, Management and Technology, 5(1). https://doi.org/10.7763/ijimt.2014.v5.479.

Priporas, C. V., Vassiliadis, C. A., Stylos, N., \& Fotiadis, A. K. (2018). The effect of sport tourists' travel style, destination and event choices, and motivation on their involvement in small-scale sports events. Event Management, 22(5), 745-765. https://doi.org/10.372 7/152599518X15299559637707.

Ross, E. L. D. \& Iso-Ahola, S. E. (1991). Sightseeing tourists' motivation and satisfaction. Annals of Tourism Research, 18(2), 226-237. https://doi. org/10.1016/0160-7383(91)90006-W.

Sato, S., Kim, H., Buning, R. J., \& Harada, M. (2018). Adventure tourism motivation and destination loyalty: A comparison of decision and non-decision makers. Journal of Destination Marketing and Management, 8, 74-81. https://doi.org/10.1016/j. jdmm.2016.12.003.

Schneider, F. (2009). Influence of the global economic crisis on the underground economy in Germany: A (renewed increase). Discussion paper. Institute of Economics, Johannes Kepler University of Linz, Linz, Austria, March 2009.
Shonk, D. J. \& Chelladurai, P. (2009). Model of service quality in event sport tourism: Development of a scale. International Journal of Sport Management and Marketing, 6(3), 292-307. https://doi. org/10.1504/IJSMM.2009.029090.

Stylos, N., Vassiliadis, C. A., Bellou, V., \& Andronikidis, A. (2016). Destination images, holistic images and personal normative beliefs: Predictors of intention to revisit a destination. Tourism Management, 53, 4060. https://doi.org/10.1016/j.tourman.2015.09.006.

Theodorakis, N. D., Kaplanidou, K., \& Karabaxoglou, I. (2015). Effect of event service quality and satisfaction on happiness among runners of a recurring sport event. Leisure Sciences, 37(1), 87-107. https://doi.or g/10.1080/01490400.2014.938846.

Van Der Merwe, P., Slabbert, E., \& Saayman, M. (2011). Travel motivations of tourists to selected marine destinations. International Journal of Tourism Research, 13(5), 457-467. https://doi.org/10.1002/ jtr.820.

Yoshida, M. \& James, J. D. (2011). Service quality at sporting events: Is aesthetic quality a missing dimension? Sport Management Review, 14(1), 1324. https://doi.org/10.1016/j.smr.2009.06.002.

Zhang, J., Byon, K. K., Williams, A. S., \& Huang, H. (2019). Effects of the event and its destination image on sport tourists' attachment and loyalty to a destination: The cases of the Chinese and U.S. Formula One Grand Prix. Asia Pacific Journal of Tourism Research, 24(12), 1169-1185. https://doi.org/10.1080/109416 65.2019 .1667837 . 